\section{Blood Xanthine Dehydrogenase and lodine Value of Blood Fatty Acids}

IN provious work using paper electrophoresis ${ }^{1}$ it was shown that the rat blood serum xanthine dehydrogenase (XD) activity migratos with tho globulin fractions, and it has boen suggested that the enzyme is bound to lipoproteins. The increase of XD activity on rat blood serum of animals poisoned with colchicine ${ }^{2}$ and of carbon totrachloride ${ }^{3}$ seems linked to a derangement of the lipid metabolism.

'The inerease of blood fatty acids in $\mathrm{CCl}_{4}$ (refs. 4 and 5) us woll as in colchicine-poisoned animals ${ }^{6}$ indicates either o pathological change in the liberation of the fatty acids by adipose tissue, or a change in the uptake and decrease of this motabolite utilization due to a modification of the fatty acid desaturation process in the liver or possibly in othor organs.

Since the increaso of tho activity in blood serum of animals poisoned with colchicine or $\mathrm{CCl}_{4}$ seems to bo a consequence of this transport lipid derangement, the purposo of the prosent communication is to study the correlation of the XD activity and the unsaturated fatty acid in rat blood serum.

Normal rats of different ages aro used in this work. $\mathrm{CCl}_{4}(0.1 \mathrm{ml} . / 100 \mathrm{~g}$ body weight) was injected into somo animals in order to obtain a range of variability in the blood scrum enzyme activity. Blood samples were withdrawn by heart puncture and each determination. was carried out on pooled non-haemolysed serum from three rats. The coagulated blood was centrifuged, and the serum was separatod and analysod immediately.

Xanthine dohydrogenaso activity was measured colorimetrically by a method previously described ${ }^{3}$ and the results were measured in ug formazan $/ 0.5 \mathrm{ml}$. serum $/ 30$ min at $37^{\circ} \mathrm{C}$. Iodino value was determined according to Yasuda ${ }^{7}$ and blood lipids determined colorimetrically by Bragdon's method ${ }^{\theta}$. 'I'wenty-two determinations woro made, tho volume boing $1 \cdot 0-2 \cdot 0$ for each assay.



The rosults showed a correlation between tho XD activity and the iodino valuo of blood serum lipids. The correlation coefficient was calculated from the duta pooled and given the value of +0.903 . The regression line is given in Fig. I ; the regression equation is $y=9.76+$ 8.67x. The actual determinations have been plotted to illustrate this relationship.

We thank Dr. G. G. Villela for his help and advice. Émilio Mitroieri OTtilia R. Afronso

Biochemical Laboratory,

Instituto Oswaldo Cruz,

Rio de Janoiro, Brazil.

${ }^{1}$ Mitidieri, E., Ribeiro, L. P., Afronso, O. 12., and Villcla, G. G., Riochim. Biophys. Actu, 17, 587 (1955).

${ }^{2}$ Affonso, 0. R., Mitidicri, E., and Villela, G. G., Nature, 193, 64 (1962).

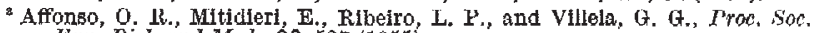
Exp. Biol. and Med., 90,527 (1955).

- Spitzer, J. J., and Miller, H. I., Proc. Soc. Exp. Biol. and Med., 92, 124 (1950).

'Villela, G. G., Biochem. Pharmacol., 13, 665 (1964).

${ }^{\circ}$ Spitzer, J. J., and Spitzer, J. A., Experientia, 15, 26 (1959),

Yasudi, M., J. Biol. Chem., 94, 401 (1031).

8 Pragilon, J., J, Biol, Chem, 190, $513(1951)$

\section{Increased Sensitivity in the Detection of Adenine and Pyridine Nucleotides by Exposure to Ultra- violet Light at Low Temperature}

IN 1957 Szent-Györgyi described a procedure for the enhancement of fluorescenco of compounds spotted on paper by cooling with solid carbon dioxide or liquid nitrogen ${ }^{1}$. (Kordon and South have applied this procedure to the action of aromatic acids and other aromatic ringcontaining compounds ${ }^{2}$. We have found that by observing absorption, Huorescence and delayed fluorescence on exposure to long and short wavo-longth ultra-violet light, $\mathrm{NAD}^{+}$and $\mathrm{NADH}$ can be distinguished from each other and from ADP and ATP.

Heat-resistant thin-laycr chromatographic plates coated with $250-\mu$ layers of silica gel (Merck-Darmstadt) or DEAE cellulose ('BIORAD') and Whatman No. 1 filter paper disks were spotted with $2 \mathrm{ml}$. ench of adenosine diphosphate (ADI), adenosino triphosphate (ATP), niacin adenine dinucleotide $\left(\mathrm{NAD}^{+}\right)$, and reduced niacin adenine dinucleotide (NADH) solutions. N $\Lambda$ DT showed a strong light bluo fluorescence, while the other compounds showed dark areas indicating absorption of the ultra-violet light when exposed to ultra-violet light at room temperature. On cooling with liquid nitrogen tho results reported in Table 1 were observed.

Maximum sensitivity in the detection of $A D P$ and ATP by both absorption and delayed fluorescence at $-196^{\circ}$ was obtained by exposure 3 in. from the shorter wave-length lamp. For observation of low levels of delayed fluorescence, the eyes were kept closed during the exposure to ultra-violet light to maintain partial dark adaptation. As soon as the exposure was ended the eyes wore opened to observe the delayed fluorescence. ADP and ATP spotted on a DEAE cellulose-coated thin-layer plate could be detected by both absorbance and delayed Huorescence with the shorter wave-length lamp at $10^{-11}$ moles at $-196^{\circ}$ and $10^{-8}$ moles by absorbance at $27^{\circ}$. When chromatograms of ADP and ATP were developed in $0.02 \mathrm{~N} \mathrm{HCl}$ (ref. 3), it was necessary to expose the plate to ammonia fumes in ordor to observe the delayed luoresconce at $-196^{\circ} \mathrm{C}$.

$\mathrm{NAD}^{+}$was distinguished from the adenine nucleotid is through reduction to NADH by application of n wenk solution of dithionito to the $\mathrm{NAD}^{+}$spot. The reduction should bo mado following the initial identification of the spots as the dithionite also absorbs nitra-violet light. Both $\mathrm{NAD}^{+}$and $\mathrm{NADH}$ could be detectod at $10^{-11}$ moles at $-196^{\circ}$.

We believe this technique, which offers a thousand-fold increase in sensitivity of detection of adenine and pyridine 